\title{
The Common Dreamscape: A Study of Dream Types in the Writings of Fedor Dostoevskii
}

\author{
JAMES LIVINGSTONE \\ University of Cambridge
}

\section{INTRODUCTION}

In January 1904, Franz Kafka wrote the following in a letter to former classmate Oskar Pollak:

\begin{abstract}
I think we ought to read only the kind of books that wound or stab us. If the book we're reading doesn't wake us up with a blow to the head, what are we reading for? So that it will make us happy, as you write? Good Lord, we would be happy precisely if we had no books, and the kind of books that make us happy are the kind we could write ourselves if we had to. But we need books that affect us like a disaster, that grieve us deeply, like the death of someone we loved more than ourselves, like being banished into forests far from everyone, like a suicide. A book must be the axe for the frozen sea within us. That is my belief. $^{1}$
\end{abstract}

Few literary works can be said to meet these oft-quoted reading requirements as actively and conspicuously as those of nineteenth century novelist, Fedor Dostoevskii. This is perhaps unsurprising, given the profound admiration Kafka expressed for his Russian predecessor, once famously referring to Dostoevskii as one of his 'true-blood relations'. ${ }^{2}$ Indeed, although the immediate source of inspiration for his 1904 remarks would appear to be the diaries of Friedrich Hebbel (all eighteen hundred pages of which Kafka claims in the same letter to have read 'all at once'), ${ }^{3}$ it is possible Kafka also had Dostoevskii in mind when he wrote of the profound psychological intensity and vigour he sought from the books that he read. The affinity between these two writers has yielded a wealth of scholarly discussion, with one critic proclaiming Dostoevskii to have been 'perhaps the single most important influence on Kafka's writing'. Dostoevskii's novels and short stories are brimming with visceral potency. The biting penetration with which the minds of his characters are infiltrated and explored establishes a

\footnotetext{
${ }^{1}$ Franz Kafka, Letters to Friends, Family and Editors, trans. by Richard and Clara Winston (New York: Schocken Books, 1977), p. 16.

${ }^{2}$ Franz Kafka, Letters to Felice, ed. by Erich Heller and Juergen Born, trans. by James Stern and Elizabeth Duckworth (New York: Schocken Books, 1973).

${ }^{3}$ Ibid., p. 15.

${ }^{4}$ W.J. Dodd, Kafke and Dostoyevsky: The Shaping of Influence (New York: St. Martin's Press, 1992), p. 106.
} 
recurrent and all-consuming force of mental dissection that fits the Kafka prescription of books that wake us up 'with a blow to the head' with noticeable conviction.

It is within one aspect of Dostoevskii's work more than any other that this intensity finds its most palpable and enduring expression - the dreams that many of his most prominent characters experience. So frequently do these dreams take place throughout his fiction, and with such vitality do they link together and relate to each other, that they come to form a special subsection of his work. The content of the dreams often varies considerably, but the space in which they occur is defined by common elements that reappear not only within individual works, but across his writings as a whole, traversing novels and novellas composed over a time period spanning more than thirty years, from the 1840s to the 1870s. Recognition of Dostoevskii's common dreamscape thus becomes essential to an understanding of the fundamental unity at the heart of his works. There are consistent, recurrent features present in Dostoevskii's world, which contribute to the broader artistic project that his novels collectively advance, namely the stated aspiration towards 'realism in a higher sense' that he personally proclaimed, ${ }^{5}$ seeking a selfconscious departure from the traditional tenets of nineteenth century realism and striving for an essentially new method of conveying reality. Robert Russell highlights the unmistakeably Modernist impulses within Dostoevskii's 'new kind of realism':

In its blend of verisimilitude and fantasy, in its instability and unpredictability, it was exactly suited to the depiction of contemporary life, and was to be a major influence through the next century. ${ }^{6}$

In this way, Dostoevskii's works were profoundly ahead of their time, and the dreams, taken together, form an integral part of the artistic movement his novels pioneered, anticipating the twentieth century project of Modernism, and prefiguring the work of writers like Kafka. Consequently, this paper seeks to uncover the distinctly Modernist traces that Dostoevskii's dreams exhibit. It is within a predominantly Modernist framework that his dreams - as a crucial component of his literary landscape - shall be examined.

The works of Sigmund Freud, another twentieth century Modernist thinker, speak back to Dostoevskii with particular clarity, with Dostoevskii's unprecedented ventures into the depths of his character's psyches laying much of the groundwork for the psychoanalytic theory Freud later developed. Although Freud's research related mostly to the dreams of human subjects, as

\footnotetext{
${ }^{5}$ Malcolm V. Jones, Dostoevsky after Bakhtin (Cambridge: Cambridge University Press, 1990), p. 2.

${ }^{6}$ Robert Russell, 'The Modernist Tradition', in The Cambridge Companion to the Classic Russian Novel, ed. by Malcolm V. Jones and Robin Feuer Miller (Cambridge: Cambridge University Press, 1998), pp. 210-229.
} 
opposed to Dostoevskiiłs fictional (if sometimes partly biographically inspired) dreams, Freudian dreamwork analysis can offer illuminating insights into several of the dreams conjured in the novels. We know that Freud read Dostoevskii and drew extensively on this valuable literary source material available to him. ${ }^{7}$ As with Kafka, the connections between the two men are far from coincidental. Louis Breger's Dostoevsky: The Author as Psychoanalyst is especially convincing in its characterisation of Dostoevskii's work as fundamentally pre-emptive of many of Freud's later discoveries. ${ }^{8}$

This paper will explore some of the most memorable and important dreams in the writings of Dostoevskii, examine the dreaming mechanism and identify the critically defining features of the Dostoevskian Dream. It will also address the functions of dreams, with their prophetic, cautionary and revelatory properties crucial to understanding their significance within his works. In demonstrating the common space in which Dostoevskii's dreams occur, three distinct dream-types emerge - Dreams of Encirclement, Dreams of Submersion and Dreams of Escape. This categorisation enables detailed and extensive comparison of dreams from a broad range of works. It allows for continuous analysis that focuses on the recurring types of dreamworld created throughout his fiction, avoiding a chronological assessment of dreams ordered in terms of the particular work to which they belong, thereby establishing the essential consistency and artistic unity with which his dreams are constructed and employed, as well as the unity of the central artistic pursuit that they serve. Each section will address one major dream in detail, before examining several further dreams that relate to the first, allowing for sustained intertextual comparison and evaluation. It is the richness of connections between dreams across Dostoevskii's writing, and the extraordinary intensity they evoke that makes them especially deserving of critical attention. More than anything else, the dreams stand out for the remarkably immersive experience they generate. The dreams carry a level of psychological and emotional suction and immersion that, to this day, remains very distinct to Dostoevskii.

In view of potentially problematic differences between the English and Russian language words that define dreams and dreaming, it is worth commenting on the critical terms at stake. This paper offers a study of what Michael Katz refers to as 'experiential dreams', ${ }^{9}$ designated in Dostoevskii's Russian as 'sny' or, less frequently, 'greay'. It is not primarily a study of figurative dreams ('mechty'), although, as Katz observes, and as this work will uncover, there is often

\footnotetext{
${ }^{7}$ Fritz Schmidl, 'Freud and Dostoevsky', Journal of the American Psychoanalytic Association, 13:3 (1965), 518-532.

${ }^{8}$ Louis Breger, Dostoevsky: The Author as Psychoanalyst (New Brunswick, NJ: New York University Press, 1989; hereafter Breger), p. 3.

${ }^{9}$ Michael R. Katz, Dreams and the Unconscious in Nineteenth-Century Russian Fiction (Lebanon, NH: University Press of New England, 1984), p. 4.
} 
considerable interplay between the figurative dreams of Dostoevskii's characters (their hopes and ambitions) and the experiential dreams that they have. This paper references Dostoevskii's texts using the 30-volume edition of his collected works, with my own translations throughout.

\section{DREAMS OF ENCIRCLEMENT}

In a morbid condition of the brain, dreams often have a singular actuality, vividness, and extraordinary semblance of reality. The resulting picture is sometimes monstrous, but the setting and the whole picture are so truth-like and filled with details so subtle, so unexpectedly, but so artistically consistent, that the dreamer, were he an artist like Pushkin or Turgenev even, could never have invented them in the waking state. Such sick dreams always remain long in the memory and make a powerful impression on the disturbed and deranged nervous system. ${ }^{10}$

This passage from Chapter 5 of the first part of Crime and Punishment (1866) offers a prime example of the clarity of insight provided throughout Dostoevskii's novels into the acute emotional power of dreams. In terms of narrative voice, it offers a jolting departure from the free indirect discourse that immediately precedes it, asserting with an almost scientific objectivity the physical incapacity of a waking mind to reproduce the dreams seen in one's sleep, even were that mind to possess the artistic capabilities of Pushkin (one of the greatest literary names of Dostoevskii's past) or Turgenev (one of the greatest names of Dostoevskii's present). Consequently, the Modernist inclinations of this novel that signal a break from the literary traditions of the day are here given explicit articulation. The passage focuses on two features that underlie the extreme, psychological force of dreams: extraordinary potential for detail and semblance of reality; and a magnetism that renders the dreamer incapable of shaking it from memory. The dream sequence that follows this extract (one of six to take place over the course of the novel) is arguably both the most intensely realistic and persistently haunting in all of Dostoevskii's work - Kenneth Lantz refers to it simply as 'the most vivid and harrowing one'. ${ }^{11}$ It is a fitting starting point for our analysis, as the opening dream in the most psychologically driven of all the novels.

Raskolnikov's dream of the mare that is cruelly flogged to death by a rabble of frenzied peasants serves as a choice illustrator of a number of features that recur in dreams throughout

${ }^{10}$ F.M. Dostoevskii, Polnoe sobranie sochinenii v tridtsati tomakh (Leningrad: Nauka, 1972-1990; hereafter PSS), VI, pp. 45-46.

${ }^{11}$ Kenneth Lantz, The Dostoevsky Encyclopedia (Westport, CT: Greenwood Press, 2004; hereafter Lantz), p. 118. 
Dostoevskii's fiction. A dream of encirclement, it deals with an experience of being surrounded, entrapped and overrun by the projections of one's unconscious. The dreams of this type are united by a striking commonality of sounds, as well as by the actions and personalities of the respective dreamers that experience them, all of whom are, to varying degrees, moral or social rebels and outcasts.

The Dream of the Mare is characterized first of all by an asphyxiating claustrophobia, generated largely through a powerful and diverse soundscape, as well as through graphically sensuous attention to fine detail. One of the most initially striking features of this dream is the cacophony of laughter, singing and raucous exclamation to which it is set. At the very beginning we are told that 'there was always a crowd there, always shouting, laughter and abuse, hideous hoarse singing and often fighting' (p. 46). The gratingly onomatopoeic Russian word 'khokbotali', used here to convey a roar of laughter, enhances the invasive, rasping nature of the noises on display. The sounds are metallic and overpowering. The clamour of the mob baying for the blood of the weakened, elderly horse is an unrelenting presence in the dream. The peasants that clamber into Mikolka's cart are continuously shown breaking into fits of laughter and singing riotously. They climb aboard the wagon 'laughing and making jokes' (p. 47). Individual cries of enthusiasm are met with the same howls of guffawing ('there was an outbreak of laughter in the crowd') while increase in the urgency and mania of the lashing reignites and re-intensifies the laughter altogether - 'the laughter in the cart and in the crowd was redoubled' (p. 47). The utterly deafening aspect of the soundtrack is conveyed with precision in the line 'all at once laughter broke into a roar and covered everything' (p. 48), which explicitly articulates the all-enveloping quality.

It is, however, the more subtle sounds from a few particular details in the scene that truly establish the sense of conglomerate, muddled tumult and uproar. Noisy consumption of food, jingling of tambourine and whistling combine to enhance the sense of chaos in the din. The woman in the cart described as 'fat and rosy' contributes a single, repeated action to the scene she 'cracks nuts and laughs' (p. 47 and repeated p. 48). This cracking combines with the percussion sound of the 'tambourine' and the 'whistling', which is noticeably heard 'in chorus' (all p. 48). The notion of musicality is picked up on by Victor Peppard, who argues that 'Dostoevsky creates a systematic acoustic orchestration, consisting of a full range of musical and sound effects, that helps to dramatize the crisis'. ${ }^{12}$ Although this observation effectively conveys the multi-layered complexity of the soundscape, the suggestion of 'systematic orchestration'

\footnotetext{
${ }^{12}$ Victor Peppard, 'The Acoustic Dimensions of Crime and Punishment', Dostoevsky Studies, 9 (1988), 143-155.
} 
detracts somewhat from the disorder. Carefully deployed the sounds may be, but it is critical not to neglect the instability and havoc evoked. Sounds appear in the scene and then dissolve with a spontaneity that heightens Raskolnikov's lack of control. It also exposes one of the crucial features of Dostoevskii's dream worlds - a state of flux and unpredictability. There is a freedom to the manner in which events within the dream unfold - things happen organically, seemingly of their own accord. René Girard likens the fluidity of development to that of a card game in which the 'the cards are laid down very rapidly' and the 'dealer' - Dostoevskii - 'lets the game proceed from beginning to end without interfering, ${ }^{13}$ which corroborates the notion of an unrestrained unravelling of action. This sense of fluid unravelling corresponds precisely to the 'instability' defined by Russell as so essential to the Modernist aspects he identifies in Dostoevskii's works.

It is, of course, not simply the volume, variety and instability of the soundtrack that generates claustrophobia, but also the jarring opposition between the conventionally celebratory noises produced by the crowd (singing, laughing, music-making, food-tasting, cheering) and the naked brutality of the spectacle entertaining them. The horrific manner in which a vulnerable mare is put to death is depicted with all the clarity suggested by the paragraph preceding it. In the caustic onomatopoeia of ' $i$ khleshchet $i$ khleshchet' ('he lashes and lashes' [p. 47]) we actually hear the violent thrashing of Mikolka's whip. The desperate final gasps and kicks of the defenceless animal are shown starkly - 'the mare stretched out her head, drew a long breath and died' (p. 48). The fact that Raskolnikov's immediate thoughts on waking focus on the gory realities of the axemurder he personally contemplates - the realities of splitting open his victim's skull and treading 'in the sticky warm blood' (p. 50) - highlights the grisly realistic nature of the dream from which he has awoken and the profoundly troubling, de-stabilizing effect on his state of mind.

As a number of commentators have observed, this dream foreshadows the murders that take place in Chapter 7 of Part 1. It also foreshadows the psychological torment - or punishment - to which Raskolnikov is subsequently subjected. The dream isolates his most fundamentally conflicting motivations by separating them into identifiable characters that appear in the dream. In the physical forms of innocent child, bloodthirsty peasant and tortured nag, we see the splitting of the dreamer into multiple character facets, each one a different side to Raskolnikov in his contemplation of murder. This 'splitting of the personality' is something Freud writes about as a fundamental tenet of the 'pathological dream', in which the dreamer, in a state of mental

${ }^{13}$ René Girard, Deceit, Desire, and the Novel: Self and Other in Literary Structure, trans. by Y. Freccero (Baltimore: Johns Hopkins University Press, 1965), p. 246. 
illness, 'hears his own thoughts uttered by alien voices'. ${ }^{14}$ As Ruth Mortimer notes, '[Mikolka's] reckless shout, "I feel as if I could kill her," is a direct statement of Raskolnikov's thought [from earlier in the novel] displaced into this situation'. ${ }^{15}$ In other words we actually hear the thoughts of Raskolnikov transplanted into the voice of another. So Mikolka can be understood not simply as symbolic of the part of Raskolnikov that wants, and believes he has a right, to go through with his murder - in a sense, he actually is that part of his mind, a contention reinforced by Louis Breger's assertion that Raskolnikov 'is peasant, young boy, and old nag' (my emphasis). ${ }^{16}$ Ultimately the dream functions within the novel to foreshadow and warn against both crime and punishment to come, to reveal the internal conflict of Raskolnikov's mind, played out in the dream as an opposition between three distinct characters (boy, peasant and horse), and to highlight the near-pathological extremity of his mental distress in this crisis moment. The revelatory aspect of the dream enhances the sense of embroilment and entrapment, as Raskolnikov is confronted by the embodiment of his own clashing instincts.

This notion of encirclement - of being surrounded and entrapped by projections of one's unconscious - is explored in the dreams of three further characters from elsewhere in Dostoevskii's writing. The first of these characters, Ippolit from the novel The Idiot (1868-69), is a 17-year-old terminal consumptive who offers a series of moving reflections on society and human existence. Though occupying a far less prominent role than Raskolnikov, Ippolit's attempts to assert his own views on life and morality in spite of the social isolation his illness imposes provide a meaningful parallel. Both are declared unbelievers that resolve to take a life, Raskolnikov through murder, Ippolit through suicide. Ippolit experiences comparably severe physical and psychological anguish to Raskolnikov, from the medical condition that afflicts him, as well as from the knowledge of his impending death. The critical comparison lies in the similarities between some of the fine details of the dreams that both characters have in a state of extreme distress. We find, for instance, many of the sounds that torment Raskolnikov in his Dream of the Mare in the two, briefer dreams of Ippolit. The first, featuring a giant scorpion-like creature that scuttles menacingly before him until being crushed in the jaws of his dog, is replete with crunches and crackles. These sounds dominate throughout, from the first indication of the reptile's presence in the room ('a kind of crackling rustle'), ${ }^{17}$ to the final moments that focus on the sound of the monster's shell which 'began to crackle' in the teeth of the dog (p. 324). Most

\footnotetext{
${ }^{14}$ Sigmund Freud, Standard Edition of the Complete Psychological Works, trans. by James Strachey (London: Hogarth, 1953; hereafter Freud), V, p. 91.

${ }^{15}$ Ruth Mortimer, 'Four Dreams in Crime and Punishment', in Readings on Fyodor Dostoyevkesy, ed. by Tamara Johnson (San Diego, CA: Greenhaven Press, 1998), pp. 67-74; hereafter Mortimer.

${ }^{16}$ Breger, p. 3.

${ }^{17}$ PSS, VIII, p. 324.
} 
significant of all is the description of the creature clacking the end of its legs and tail against the floor, which makes use of the very same verb ("shchelkat'/poshchelkat") [p. 324]) employed in Raskolnikov's dream to depict the cracking of nuts. Ippolit's second, even briefer dream of an enormous tarantula actually features laughter - the most dominant, underpinning noise of the Raskolnikov soundscape - as Ippolit sketches the fearsome spider that laughed at [his] indignation' (p. 340). Thus, Ippolit and Raskolnikov - characters from two different novels find themselves confronted and surrounded by near-identical sounds as their dreaming ordeals become heightened to a point of almost unendurable intensity.

Though Ippolit's dreams are shorter and less elaborately populated than Raskolnikov's Dream of the Mare, his experiences carry similar functional properties - they are prophetic and revelatory, foreshadowing his approaching destruction, and exhibiting his internal fear of the descent into oblivion. The dread of slipping into an eternity of unknown darkness is presented with particular clarity in the second dream, whose monster acquires its horror as much from its other defining qualities - 'dark', 'deaf' and 'mute' (all p. 326) - as from its imposing size. The first dream, meanwhile, deals explicitly with death. The dog responsible for killing the scorpion has itself been resurrected in the dream, with Ippolit noting that she 'had died five years ago' ( $\mathrm{p}$. 324), while the reptile is shown to be capable of delivering a lethal attack even as it is being killed, through a final stinging assault onto the tongue of the yelping canine.

The other characters from Dostoevskii's works who have dreams of encirclement - Liza, from The Brothers Karamazov (1879-80) and Goliadkin from The Double (1846) - also share more in common with Raskolnikov than is immediately apparent. Liza is a comparatively minor figure an excitable and romantically fickle young girl suffering from partial paralysis. Her inability to find happiness and love ultimately leads to self-loathing, plunging her into a self-destructive despair not unlike the affliction Raskolnikov experiences in the aftermath of his crimes. There are remarkable similarities in the way her psychological suffering manifests itself within the dream she experiences in the chapter 'A Little Demon'. Many tiny devils appear in a flash and surround her on all sides:

Suddenly there are devils all over the place, in all the corners, under the table, and they open the doors; there's a crowd of them behind the doors and they want to come and seize me. And they are just coming, just seizing me. ${ }^{18}$

The use of the word 'crowd' ('tolpa' in the original Russian) to describe the gang of devils lying in wait offers an unmistakable parallel with the Dream of the Mare, where Raskolnikov is encircled

${ }^{18}$ PSS, XV, p. 23. 
by his own 'tolpa' of peasants. The absolute pervasiveness of the devils is obvious from the way they are located all around the room, wherever Liza casts her eye, be it in the corner, under the table or in the doorway. Although Liza suggests she has some control over their advancement, explaining that the act of crossing herself forces them into momentary retreat, the initial, instantaneous and ubiquitous emergence of these devils in her dream is something she is powerless to prevent.

Similarly, Goliadkin, the main character in a much shorter work (a government clerk driven mad by a series of bizarre encounters with his apparent doppelganger), is powerless to combat the initial appearance of the monsters that swamp his dream in Chapter 10 of The Double, towards the end of the novella. Like Liza's devils, Goliadkin's tormentors arrive without introduction - they are conjured instantaneously, emerging 'as though out of the ground'. ${ }^{19}$ Goliadkin finds himself at the mercy of his unconscious, clones of himself popping up before him with every step he takes. The image of a multiplying 'file of geese' [p. 187]) hobbling manically after him evokes random chaos, while the inescapability of the experience is shown unambiguously with the simple comment that 'there was nowhere to escape' (p. 187). The wild unpredictability of the geese-like duplicates provides a clear example of the spontaneous unravelling of action mentioned earlier that is so characteristic of Dostoevskii's dream worlds.

The revelatory component of these two dreams can be understood relatively straightforwardly. The hoard of devils coming for Liza vividly illustrates her longing for selfdestruction, both emotional and physical. It also foreshadows her self-harm after waking at the end of the chapter, when she intentionally crushes her finger in a door jamb (providing yet another example of the 'cracking' noise common to this dream type). Goliadkin's dream illustrates a mind on the verge of complete ruin, as the confusion and paranoia of his conscious existence turns to unconscious embroilment. Ultimately Liza and Goliadkin find themselves invaded, surrounded and overwhelmed in ways that are highly compatible with the experiences of both Raskolnikov and Ippolit.

The five dreams explored in this opening section provide important examples of Dostoevskii's Dreams of Encirclement. They deal with invasion and entrapment. United by common elements within their soundscapes (with noises of cracking and laughter especially pervasive), as well as by similarities in the individuals that experience them, these dreams are connected not only by the forms they take and the sensations they evoke, but also by the functions they serve, namely prophecy and revelation, foreshadowing events to come, and exposing the psychological struggles and conflicts of the characters who experience them.

\footnotetext{
${ }^{19}$ PSS, I, p. 187. 


\section{Dreams of Submersion}

The second category of Dostoevskian dream-type involves dreams that plough the very deepest and most troubled recesses of the human psyche - these are the experiences of characters who engage in some of the most extreme forms of immoral and antisocial behaviour, with the abuse and degradation of children a common thematic feature. Unlike the Dreams of Encirclement, in which characters are surrounded and overwhelmed by external projections (whether frenzied peasants, monstrous invertebrates or tiny devils), the dreamers of this section find themselves submerged in past memories that come back to haunt them. This submersion frequently takes the form of literal inundation, as torrential rain and pools of water often dominate the experiences. The first character to have such a dream is Svidrigailov from Crime and Punishment. Often seen by critics as Raskolnikov's 'double, ${ }^{20}$ Svidrigailov wrestles with the unconscious demons of what is generally considered the most unspeakable crime of all, the abuse and molestation of children. His sequence of four dreams fused together sends him down a tunnel of darkness and revulsion from which he never returns, as suicide follows awakening. The dream sequence, experienced right at the end of the book in Chapter 6 of Part 6 , offers a stormy cauldron of distressing physical sensations and hair-raising images. It exhibits extreme claustrophobia, as well as disorientation and confusion, as the victims of Svidrigailov's past return to afflict him with an intolerable torment.

Traditional interpretations of Svidrigailov tend to present him as the straightforward villain of the novel, a man fundamentally incapable of compassion for others. Breger is especially unequivocal: 'he has no conscience, feels no guilt, all acts are of equal value - or lack of value to him'. ${ }^{21}$ Recent appraisals have offered some resistance to this view, with Carol Apollonio's Dostoevsky's Secrets: Reading Against the Grain (2009) convincingly arguing for a less damning assessment, noticing a divergence between the waking acts we see him carry out, and the shocking crimes we discover within his unconscious visions. ${ }^{22}$ What his dream sequence in fact unearths is a deeply embedded sense of regret for his transgressions that, once uncovered, becomes too agonizing to bear. The sequence is dominated by detailed, sensuous description of the natural scenery. Rain, thunder, wind and cold assault Svidrigailov throughout the dreams, as well as in the waking build-up and aftermath. The maelstrom of gushing and whirling conjured

\footnotetext{
${ }^{20}$ Breger, p. 43.

${ }^{21}$ Ibid.

${ }^{22}$ Carol Apollonio, Dostoevsky's Secrets: Reading Against the Grain (Evanston, IL: Northwestern University Press, 2009). 
by the tumultuous weather gives the psychological embroilment a suffocating quality, evocative of drowning.

Following rejection by Dunia (the woman he loves), Svidrigailov's nightmares take place on a cold, dark and rainy evening in which he finds refuge in a small hotel room after wandering the streets aimlessly. The overbearing aggression of the pre-dream climatic setting is obvious from the thunder that 'clapped', ${ }^{23}$ and the rain that 'poured like a waterfall' and 'fell not in drops, but beat on the earth in streams' [all p. 384]). The 'frightening clouds', said to have gathered 'on all sides' (both p. 384), create an immediate sense of encirclement, noticeably comparable to the dreams of the previous section. The physical assault on Svidrigailov's body is repeatedly emphasized - the torrential downpour renders him 'drenched to the skin' [p. 384]), later simply 'wet through' [p. 385]), while the howling wind gives him a feverish chill, underscored by multiple references to shivering ('he began to shiver' and then 'he soon felt very cold' [both p. 388).

The encroachment of the weather into the dream-world that Svidrigailov slips into as he lies down makes for an extraordinarily disorientating experience, with the boundary between dream and reality losing clear definition. Temira Pachmuss writes of this boundary being 'almost entirely obliterated', ${ }^{24}$ a statement with an inherent violence wholly appropriate to the scene. The sequence divides loosely into four sections: a first, featuring the rising image of Dunia and then a darting mouse; a second that focuses on the 15-year-old girl he has ostensibly abused, lying coffined in a peaceful garden; a third in which Svidrigailov experiences a false awakening; and a final section where he is confronted by a very young girl whose face acquires the mocking expression of a luring prostitute, and whose 'depravity' (p. 393) frightens and appals him. Driving rain and roaring wind provide uninterrupted accompaniment to each section. Svidrigailov is continually bothered by the cold and wet of his waking reality: in the first section we are told that 'he felt fearfully disinclined to get up, pull of the blanket [and] freeze' (p. 390); in the second he recalls the scene of one of his crimes to the same backdrop as the current storm ('on a dark night, in the gloom, in the wet [...] while the wind howled'[p. 391]); in the third he envisions a park bush 'all drenched with rain 'from which 'a million drops will drip in one's head' [both p. 392]); and the trembling girl of his final dream is initially characterised by her feet, described as 'wet as though they had been standing in a puddle all night' [p. 393].

\footnotetext{
${ }^{23}$ PSS, VI, p. 384.

${ }^{24}$ Temira Pachmuss, 'The Technique of Dream-Logic in the Works of Dostoevskij', The Slavic and East European Journal, 4:3 (1960), 220-242; hereafter Pachmuss.
} 
This set of complexly knitted-together dream scenes functions slightly differently to those already examined. As with the Dreams of Encirclement, there is a clear, revelatory purpose to Svidrigailov's sequence, articulating the psychological strife of a mind incapable of extinguishing the horrors of past events. The fact that he is haunted by his victims does not in itself demonstrate remorse, but it does show at least a degree of what Kenneth Lantz calls Svidrigailov's 'unconscious disgust with himself. ${ }^{25}$ The intolerable revulsion that the image of the young girl instils reveals hidden regret that, ultimately, compels him to suicide. There is, however, a crucial difference in the function of this dream - while the dreams of the first section all focus towards future events yet to take place (Raskolnikov's murders and suffering, Ippolit's death, Liza's self-harm and Goliadkin's insanity), Svidrigailov's are based on past experiences brought back to plague him. The actual dream-world is extensively comparable to those already examined - there are even overlapping elements in the soundscape, such as the laughter of the girl in his final dream, qualified by the same term - 'hideous' ('bezobrasnyi' [p. 393]) - as the laughter that assaults Raskolnikov at the beginning of the novel.

Thematically, the most obviously analogous dream to Svidrigailov's from elsewhere in Dostoevskii's writing is Stavrogin's dream of Matresha in Devils (1871-2). There are clear, superficial parallels - both centre on a child rapist haunted by the image of their victim, in both instances a young girl driven to suicide. In Stavrogin's dream we do not, however, find the same dramatic weather imagery that dominates Svidrigailov's experience. What is apparent throughout Stavrogin's nightmare, though, is the same ferocious emotional intensity of encounter. There is also the shared function of unearthing guilt in the mind of a character normally otherwise regarded as incapable of feeling it. And though Stavrogin's dream also centres on a past event reconjured, his is presented as a precisely accurate replication of the past experience - unlike Svidrigailov, in whose sequence faces and images appear one after another with surreal fluidity, Stavrogin experiences his dream as though the particular moment recalled were actually taking place.

In contrast to the many dreams in Dostoevskii's fiction narrated in the present tense, and, thus, relayed in the very moment of the character's experience, Stavrogin's dream is told in retrospect in a letter during a religious confession. The episode comes from the censored chapter 'At Tikhon's', not published until 1922, 41 years after Dostoevskii's death. The depiction is consequently more heavily mediated and detached from the main narrative of the novel than Svidrigailov's in Crime and Punishment. The raw psychological power of Stavrogin's experience is, however, brought out with much the same intensity. In the dream Stavrogin is returned to the

${ }^{25}$ Lantz, p. 119. 
scene of Matresha's suicide, which he describes extensively from waking memory earlier in the chapter. The dream version is replete with all the fine details of the original - the 'tiny reddish spider, ${ }^{26}$ the 'geranium leaf (p. 22), the young girl, 'emaciated and with feverish eyes' [p. 22]) are all retained. Stavrogin specifies that he saw the girl in every point exactly as she was when she stood on the threshold of my room' (p. 22), showing the extraordinary precision with which the memory is reproduced. The image of Matresha shaking her head and raising her tiny fist is painfully distressing for Stavrogin, just as the laughter and lewd grin of the girl in Svidrigailov's dream is unbearable for him. The profound psychological effect of the vision of Matresha on Stavrogin is evident from his assertions that 'never was anything so unbearable to me' (p. 22) and 'it was as though something were plunged through me' (p. 22), lines revealing a man in a state of anguish, as he is forced to re-experience a moment whose vivid recollection he cannot escape.

It is, however, another dream from Dostoevskii's works that corresponds most actively to Svidrigailov's - the dream of the Ridiculous Man from The Dream of a Ridiculous Man (1877). Despite appearing superficially to bear less in common with the nightmare of Svidrigailov than that of Stavrogin (this dream does not concern a child molester, and although suicide is a central preoccupation, no one actually dies here), the dreaming experience itself is in many ways more consistently comparable. The story's protagonist, a man disillusioned with his own existence, and on the brink of suicide, finds new enthusiasm for life after a chance meeting with a young girl and then an extended dream sequence. The dominance of the natural elements in this sequence, especially rain and cold, is noticeably similar to Svidrigailov's. The outdoor conditions in the dream's build-up are (with the exception of the howling wind that does not feature) essentially the same:

Rain had been falling all day, and it had been a cold, gloomy, almost menacing rain [...] Suddenly between ten and eleven it had stopped, and was followed by a fearful dampness, colder and damper than the rain. ${ }^{27}$

Many of the same terms are used. The 'gloomy rain' ('mrachnyi dozhd") and 'fearful dampness' ('strashnaia syrost”) parallel the 'gloomy evening' ('mrachnyi vecher') and 'fearful clouds' ('strashnye tuchi') of Svidrigailov's setting, while the 'menacing' rain injects the oppression conjured in Svidrigailov's dream by the circling clouds. There are also copious similarities between the girls that feature in the two experiences - for instance, the 'wet broken shoes' (p. 106) of the Ridiculous Man's girl mirror the drenched feet of Svidrigailov's imagined child. Both girls cry out in desperation for their mothers - the Ridiculous Man's calling for 'mamochka' (p. 106),

\footnotetext{
${ }^{26}$ PSS, XI, p. 22.

${ }^{27}$ PSS, XXV, p. 105. 
Svidrigailov's calling to 'mamasia', both variations on affectionate cries for 'mummy'. Each girl serves a critical purpose - while the lasting effect of an imagined, soaking girl on the mind of Svidrigailov is to spur him to suicide, the effect on the Ridiculous Man of a strikingly similar girl (though not the victim of sexual abuse) is to save him from such a fate, as he explains: 'No doubt I would have shot myself had it not been for that little girl' (p. 106). Rain and cold penetrate the entire sequence in both cases, with the invasive assault of the weather maintained even in the fantastical, abstract moments of the Ridiculous Man's dream, such as one in which he imagines himself buried alive (itself a point of comparison with the coffined girl of Svidrigailov's dream) and his closed left eyelid is struck by a single 'drop of water' (p. 110) even from inside his coffin. In addition to these similarities of the dream of the Ridiculous Man with Svidrigailov's dream, there are also remarkable parallels with a dream that Stavrogin has immediately before his vision of Matresha. This will be looked at in more detail in the next section.

Ultimately the dreams addressed in this second section - dreams that show characters immersed in past memories of extreme, transgressive behaviour - are useful in demonstrating the all-consuming intensity of experience so particular to the Dostoevskian dream. They are united by their quality of submersion, with dreamers literally overwhelmed by water, as in the case of Svidrigailov and the Ridiculous Man, and more broadly submerged figuratively in episodes of unbearable recollection, as is the case with all three. Analysis of these dreams of submersion reveals a commonality of elements within this dream category, but which also extends back to the dreams of the first category - encircling clouds and the recurrence of laughter in the soundscapes ensure crucial interconnection between the categories. In the extraordinary richness of parallels between dreams throughout Dostoevskii's works, his dreamers come to share common space, so often do they find themselves in the same natural environments, confronted by the same physical sensations, even haunted by the same kinds of images. Unlike the Dreams of Encirclement, the three explored here are concerned more with uncovering and re-living past experience than foreshadowing events to come. They expose brief glimpses of humanity in characters otherwise portrayed as lacking the most basic human sympathies, revealing potential for guilt and regret even in the minds of child molesters. They can also have epiphanic function, most strikingly conveyed in the case of the Ridiculous Man, a person whose dream actually brings him back from the verge of killing himself. 


\section{DREAMS OF ESCAPE}

Not all of Dostoevskii's fictional dreams deal with anguish, suffering and despair. Even the characters that experience the most terrifying nightmares sometimes have dreams of peace and serenity, offering rare moments of respite from the torturous preoccupations of their waking lives. In the chapter following the Dream of the Mare in Crime and Punishment, Raskolnikov experiences a second, much briefer dream, in which he imagines a camel train at rest in the tranquil surroundings of a watering hole. The precise location of this desert paradise is uncertain - he simply imagines himself 'somewhere in Africa, in Egypt, at some oasis' ${ }^{28}$ The vagueness of setting instils mysticism and wonder that elevate the blissful harmony of the scene to that of an almost celestial sanctuary. The experience is conveyed with the greatest brevity of all of Dostoevskii's major dreams:

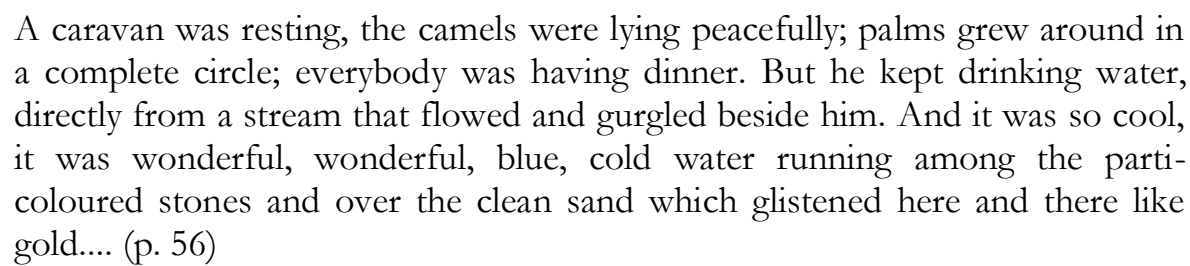

This fleeting nature of this dream has often led to it being overlooked by commentators entirely - Ruth Mortimer's study of Raskolnikov's 'Four Dreams in Crime and Punishment', for example, does not even acknowledge it. ${ }^{29}$ However, as David Matual in particular points out, when considered in conjunction with the scene immediately preceding Raskolnikov's embrace of Sonia in the novel's epilogue, this dream becomes 'one of the major passages in the novel, since its imagery clearly foreshadows the hero's conversion'. ${ }^{30}$ In the epilogue Raskolnikov finds himself once again beside a body of water in a landscape of otherwise unbroken wilderness. He encounters nomads, who correspond unmistakeably to the travelling caravan of the oasis dream. It is at this moment that Sonia sits next to him, and Raskolnikov collapses in tears, throwing his arms around her knees, before both feel overcome by 'the dawn of a new future, of a full resurrection into a new life' (p. 421). Through the qualities of redemption and renewal to which the oasis vision thus becomes intrinsically tied, the dream acquires a far profounder significance than is generally acknowledged. Redemption, renewal and reconciliation are central to the

\footnotetext{
${ }^{28}$ PSS, VI, p. 56.

${ }^{29}$ Mortimer.

${ }^{30}$ David Matual, 'In Defense of the Epilogue of Crime and Punishment', in Bloom's Modern Critical Interpretations: Crime and Punishment, ed. by Harold Bloom (New York: Chelsea House Publishers, 2004), pp. 105-115.
} 
thematic features that unify dreams of this third type - dreams in which characters are transported to far-off realms, surrounded by sights and sounds of sweet idyll, and momentarily freed from the psychological torments of their waking lives.

The soothing display of Raskolnikov's desert scene is shown from the 'resting' caravan, the 'peacefully' lying camels, and the palms, whose framing arrangement suggest a natural unity and wholeness reinforced by the framing syntax of 'krugom [...] krugom' ('in a circle [...] in a circle') of the Russian text. The soft babbling of the brook is conveyed delicately, with the cool relief and revitalizing allure of the water given special emphasis through repetition of 'wonderful' and the rhyming of 'takaia golubaiai ('so blue'). Multi-coloured stones combine with dazzling sand to offer a final image of wonderment before the dream is dispelled, as Raskolnikov is returned to the mental frenzy of his waking reality by the violence of a striking clock - 'Suddenly he heard a clock strike' (p. 56).

In contrast to the Dreams of Encirclement and Submersion, here the dreamer is immersed in a moment of peaceful shelter, so there is no claustrophobia or entrapment. There is, however, a similar level of absorption and intensity of experience. The dream offers a total escape - for the briefest of moments Raskolnikov is free, untroubled, bathed in serenity. The intensity comes from the vividness of the colours, the detail in the images, the gentle sounds of the gargling stream (which negate the severe noises of the Dream of the Mare) and the magnetic appeal of the water in the barren wilderness. The sudden strike that brings Raskolnikov back to the real world shows the potency of immersion in the imaginary realm of his unconscious mind. He wakes with a frightful start, as we are told he 'suddenly jumped up wide awake, as though someone had pulled him off the sofa' (p. 56).

For Raskolnikov this dream is an escape from the turmoil he experiences in his contemplation of murder. His revulsion at the barbaric destruction of the feeble nag in his first dream, and the fear and doubt instilled in him, is momentarily cast aside. The oasis places him in a distant fantasy land, removed from his present reality and the emotional tumult that has begun to plague him. The dream is an example of what Jacques Catteau refers to as 'a glimpse of the mirage of supreme freedom, ${ }^{31}$ which Dostoevskii's characters experience as their 'yearning for peace leads [them] [...] to the havens of eternity. ${ }^{32}$ In these moments, Catteau explains, 'space opens out like a soothing infinity in which mutilating time, experienced as intolerable stress and agony, fades out of sight'. ${ }^{33}$ The notion of emotional distress 'fad[ing] out of sight' is felt acutely

\footnotetext{
${ }^{31}$ Jacques Catteau, Dostoevsky and the Process of Literary Creation (Cambridge: Cambridge University Press, 1989; hereafter Catteau), p. 382.

${ }^{32}$ Ibid.

${ }^{33}$ Catteau, p. 383. 
as, for as long as the dream lasts, Raskolnikov occupies a paradisiacal realm in which the time of his reality is effectively suspended. The 'eternity' and 'infinity' of this particular sequence is inherent in the image of an oasis, a universal symbol of refuge and recovery from the harsh endless expanse of desert.

The Dream of the Oasis also has a more practical, incidental function, fulfilling Raskolnikov's physical desire to quench his thirst, after falling asleep feverish and dehydrated. Freud's comment on one of his own dreams - a similar 'dream of convenience' in which genuine thirst is temporarily relieved by imagined hydration - articulates the powerful illusion that such 'undisguised wish-fulfilment' can impose: '[In the dream] I gulp down water in deep draughts, and it tastes as delicious as only a cool drink can be when one is parched, and then I wake up and have to drink in reality' ${ }^{34}$ This quotation mirrors the near-intoxicating relief of Raskolnikov's oasis scene, followed by the abrupt return to the distinctly unquenched discomfort of his conscious life.

There are obvious connections between Raskolnikov's Dream of the Oasis and the recurring Dream of the Golden Age, a dream experienced by characters across three different works - Stavrogin in Devils (prior to his dream of Matresha), Versilov in The Adolescent (1875) and the Ridiculous Man in The Dream of a Ridiculous Man (following the vision of his own burial). All three versions of this dream take place in the Greek archipelago and feature gentle, caressing waves, a population of beautiful, happy people, and idyllic views of sunset landscapes. The vision is paradisiacal, with the word ' $r a \imath$ ' ('paradise') fundamental to each rendition. There is imprecision of location in all three, providing an ethereal quality to the experience, just as in the Dream of the Oasis. The 'magic vista on the horizon' mentioned by Stavrogin and Versilov, ${ }^{35}$ and conjured through imagery by the Ridiculous Man, is reminiscent of Raskolnikov's mystical desert refuge. The verdant meadows of each Golden Age depiction suggest natural abundance and vitality, similar to the oasis, in which life flourishes because of the flowing stream. 'Caressing waves' evoke the gentle, ${ }^{36}$ enticing trickle of the oasis brook. The coupling of such detailed natural imagery with the transcendence of the ambiguous setting makes these dreams good examples of what is described by Pachmuss as 'Dostoevskij's artistic skill in combining unadorned realism

\footnotetext{
${ }^{34}$ Freud, V, p. 123.

${ }^{35}$ PSS, XI, p. 21, PSS, XIII, p. 375.

${ }^{36}$ PSS, XI, p. 21, PSS, XIII, p. 375, PSS, XXV, p. 112. 
with the means of mystification', ${ }^{37}$ and by Ralph Matlaw as 'an interpenetration of "naturalistic" and metaphysical elements'. ${ }^{38}$

The dream of the Golden Age is an escape for Stavrogin, Versilov and the Ridiculous Man, just as the Dream of the Oasis is for Raskolnikov. As Catteau points out, the Golden Age dream is reserved exclusively for characters 'guilty of harming children' - the Ridiculous Man rejects a despairing little girl crying for her mother, Versilov (a neglectful and womanizing father) abandons his son Arkadii, while Stavrogin, as already detailed, rapes a young girl who then hangs herself. ${ }^{39}$ The dream offers a calming retreat from the emotional chaos that afflicts these characters. The Golden Age is utopian not only in the pristine beauty of the landscape, but also in its romantic ideal of humanity - the dream-world is one in which people are 'happy' and 'beautiful', ${ }^{40}$ but also expressly 'innocent', ${ }^{41}$ and 'not sinful'. ${ }^{42}$ Such reference to innocence draws attention to a shared yearning for escape from the responsibility and guilt of transgression, which Catteau neatly summarises as 'the desperate evasion of a tortured mind trying to find a state where all individual guilt is wiped out'. ${ }^{43}$

The notion of a dream that recurs not simply in the mind of one individual, but in the minds of multiple characters across various texts is important in illustrating the common space that Dostoevskii's dreamers inhabit. Not only do his characters have dreams that correspond and relate to each other, they even sometimes have dreams that are essentially identical. The dreams of this third section contrast sharply with those of the first and second. Rather than dealing with frightening and repellent experiences, the Dreams of Escape concern visions of serene beauty, freedom and relief, momentarily freeing their dreamers from the torment of excruciating waking guilt. As with all the dreams examined earlier, these character's experiences are brimming with emotional intensity - so profoundly affected by their dreams of the Golden Age are Stavrogin and Versilov that they declare, using identical words:

[...] I woke and opened my eyes and, for the first time in my life, found them full of tears. A feeling of happiness, until then unfamiliar to me, went through my whole heart, even painfully. ${ }^{44}$

\footnotetext{
${ }^{37}$ Pachmuss.

${ }^{38}$ Ralph E. Matlaw, 'Structure and Integration in Notes from the Underground', PML $A, 73: 1$ (1958), 101-109.

${ }^{39}$ Catteau, p. 375.

${ }^{40}$ PSS, XI, p. 21, PSS, XIII, p. 375.

${ }^{41}$ Ibid.

${ }^{42}$ PSS, XXV, p. 112.

${ }^{43}$ Catteau, p. 375.

${ }^{44}$ PSS, XI, p. 22, PSS, XIII, p. 375. 
This outpouring of feeling is not delivered by the Ridiculous Man, but he conveys the same sentiment with another, similar outburst:

[...] The sensation of the love of those innocent and beautiful people has remained with me for ever, and I feel as though their love is still flowing out to me from over there. 45

The acute emotional impact that these dreams have on the characters is cemented in these effusions, which highlight the unshakeable, enduring quality, a quality mentioned explicitly by Dostoevskii in the passage from Crime and Punishment cited at the beginning of the first section of this paper.

\section{CoNCLUSiON}

Detailed discussion of a wide selection of dreams spanning five of Dostoevskii's novels and two shorter works has yielded a number of conclusions. Common to all the dreams explored in this paper is an all-consuming immersive power that sucks characters into unconscious experiences of extreme intensity. The dreams are packed with energy, movement, colour and richly evocative, sensuously charged imagery. Analysis of the three identified dream types (Dreams of Encirclement, Dreams of Submersion and Dreams of Escape) reveals a remarkable commonality of features not merely within these individual types, but spreading across the categories, ultimately uncovering a common Dostoevskian dreamscape, in which characters encounter shared images and sensations, ranging from the subtlety of a single recurring sound to the reproduction of an entire fantasy land.

The following words of Virginia Woolf, one of the most celebrated Modernist writers of the twentieth century, bear great relevance to this discussion:

The novels of Dostoevsky are seething whirlpools, gyrating sandstorms, waterspouts which hiss and boil and suck us in. [...] Against our wills we are drawn in, whirled round, blinded, suffocated, and at the same time filled with a giddy rapture. ${ }^{46}$

It is within Dostoevskii's dreamscape that this rawness and intensity of experience so treasured by Modernists like Woolf is most powerfully expressed.

${ }^{45}$ PSS, XXV, p. 112.

${ }^{46}$ Virginia Woolf, 'The Russian Point of View', in The Common Reader (London: Vintage, 2003), p. 178. 
Dostoevskii's characters are engulfed and embroiled, dragged under, surrounded and swallowed up by their unconscious imaginings, in ways that fully anticipate the Modernist fascination with the previously unchartered depths of human psychology.

The primary function of the dreams is to shed light on the innermost conflicts of the characters and expose their most deeply embedded incentives, inclinations, anxieties and aversions. They can act as a time capsule, foreshadowing and warning against the perils of future events yet to occur, or revisiting the critical moments of a character's past. They can be highly complex in their functional properties, splintering the dreamer into multiple variations of the self, or more simplistic, offering a thirsty dreamer the drink of water their sleeping mind craves. They are also fraught with volatility, so erratically can the action within them unfold, and with such suddenness can one dream morph into another or disappear entirely. Inexhaustible in sheer variety and intricacy, yet simultaneously tightly connected and infinitely comparable, they are unique in the penetrative insight they provide.

Jacques Catteau concludes his critical study with the comment that Dostoevskii's works 'endlessly respond and vibrate like the flesh and soul of a living creature'. ${ }^{47}$ Completing the simile, the dreams are like the beating heart that keeps the creature breathing, and keeps the blood flowing. For it is within them that we find the very greatest intensity, the most sparkling vibrancy, the most unbridled power. Returning to Kafka, it is Dostoevskii's dreams, more than any other aspect of his writing, that strike like the axe for the frozen sea within us.

\footnotetext{
${ }^{47}$ Catteau, p. 447. 


\section{BIBLIOGRAPHY}

Apollonio, Carol, Dostoevsky's Secrets: Reading Against the Grain (Evanston, IL: Northwestern University Press, 2009)

Breger, Louis, Dostoevsky: The Author as Psychoanalyst (New Brunswick, NJ: New York University Press, 1989)

Catteau, Jacques, Dostoevsky and the Process of Literary Creation, trans. by Audrey Littlewood (Cambridge: Cambridge University Press, 1989)

Dodd, W. J., Kafka and Dostoyeusky: The Shaping of Influence (New York: St. Martin's Press, 1992)

Dostoevskii, F. M., Polnoe sobranie sochinenii v tridtsati tomakh, 30 vols (Leningrad: Nauka, 19721990)

Freud, Sigmund, Standard Edition of the Complete Psychological Works, trans. by James Strachey, 24 vols (London: Hogarth, 1953)

Girard, René, Deceit, Desire, and the Novel: Self and Other in Literary Structure, trans. by Y. Freccero (Baltimore, MD: Johns Hopkins University Press, 1965)

Jones, Malcolm V. Dostoevsky after Bakhtin (Cambridge: Cambridge University Press, 1990)

Kafka, Franz, Letters to Felice, ed. by Erich Heller and Jürgen Born, trans. by James Stern and Elizabeth Duckworth (New York: Schocken Books, 1973)

Kafka, Franz, Letters to Friends, Family and Editors, trans. by Richard and Clara Winston (New York: Schocken Books, 1977)

Katz, Michael R., Dreams and the Unconscious in Nineteenth-Century Russian Fiction (Lebanon, NH: University Press of New England, 1984)

Lantz, Kenneth, The Dostoevsky Encyclopedia (Westport, CT: Greenwood Press, 2004)

Matlaw, Ralph E., 'Structure and Integration in Notes from the Underground', PML $A, 73: 1$ (1958), 101-109 
Matual, David, 'In Defense of the Epilogue of Crime and Punishment', in Bloom's Modern Critical Interpretations: Crime and Punishment, ed. by Harold Bloom (New York: Chelsea House Publishers, 2004), pp. 105-115

Mortimer, Ruth, 'Four Dreams in Crime and Punishment', in Readings on Fyodor Dostoyevksy, ed. by Tamara Johnson (San Diego, CA: Greenhaven Press, 1998)

Pachmuss, Temira, 'The Technique of Dream-Logic in the Works of Dostoevskij', The Slavic and East European Journal, 4:3 (1960), 220-242

Peppard, Victor, 'The Acoustic Dimensions of Crime and Punishment', Dostoevsky Studies, 9 (1988), 146-148

Russell, Robert, 'The Modernist Tradition', in The Cambridge Companion to the Classic Russian Novel, ed. by Malcolm V. Jones and Robin Feuer Miller (Cambridge: Cambridge University Press, 1998), pp. 210-229

Woolf, Virginia, 'The Russian Point of View', in The Common Reader (London: Vintage, 2003)

This work is licensed under the Creative Commons Attribution-NonCommercial-ShareAlike 3.0 Unported License. To view a copy of this license, visit http://creativecommons.org/licenses/bync-sa/3.0/ or send a letter to Creative Commons, PO Box 1866, Mountain View, CA 94042, USA. 